ORNL/TM-5664

\title{
ORNL Fusion Power Demonstration Study: Arguments for a Vacuum Building in Which to Enclose a Fusion Reactor
}

Richard W. Werner

\section{MASTER}

OAK RIDGE NATIONAL LABORATORY 


\section{DISCLAIMER}

This report was prepared as an account of work sponsored by an agency of the United States Government. Neither the United States Government nor any agency Thereof, nor any of their employees, makes any warranty, express or implied, or assumes any legal liability or responsibility for the accuracy, completeness, or usefulness of any information, apparatus, product, or process disclosed, or represents that its use would not infringe privately owned rights. Reference herein to any specific commercial product, process, or service by trade name, trademark, manufacturer, or otherwise does not necessarily constitute or imply its endorsement, recommendation, or favoring by the United States Government or any agency thereof. The views and opinions of authors expressed herein do not necessarily state or reflect those of the United States Government or any agency thereof. 


\section{DISCLAIMER}

Portions of this document may be illegible in electronic image products. Images are produced from the best available original document. 
Printed in the United States of America. Available from National Technical Information Service

U.S. Department of Commerce

5285 Port Royal Road, Springfield, Virginia 22161

Price: Printed Copy $\$ 4.00$; Microfiche $\$ 3.00$

This report was prepared as an account of work sponsored by the United States Government. Neither the United States nor the Energy Research and Development Administration/United States Nuclear Regulatory Commission, nor any of their employees, nor any of their contractors, subcontractors, or their employees, makes any warranty, express or implied, or assumes any legal liability or responsibility for the accuracy, completeness or usefulness of any information, apparatus, product or process disclosed, or represents that its use would not infringe privately owned rights. 
ORNL/TM-5664

D1st. Category UC-20

Contract No. W-7405-eng-26

ORNL FUSION POWER DEMONSTRATION STUDY :

ARGUMENTS FOR A VACUUM BUILDING IN

WHICH TO ENCLOSE A FUSION REACTOR

RIchard W. Werner*

Date Published: December 1976

* On leave from Lawrence Livermore Laboratory

Livermore, Callfornia

NOTICE: This document contains information of preliminary nature. It is subject to revision or correction and therefore does not represent a final report.

OAK RIDGE NATIONAL LABORATORY

Oak Ridge, Tennessee 37830 operated by

UNION CARBIDE CORPORATION

for the

ENERGY RESEARCH AND DEVELOPMENT ADMINISTRATION

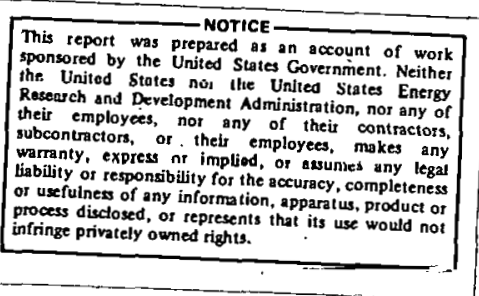




\section{ABSTRACT}

Fusion reactors as presently contemplated are excessively complicated, are virtually Inaccessible for some repairs, and are subject to frequent loss of function. This dilemma arises in large part because the closed surface that separates the "hard" vacuum of the plasma zone from atmospheric pressure is located efther at the first wall or between blanket and shield. This closed surface is one containing hundreds to thousands of linear meters of welds or mechanfcal seals which are subject to radiation damage and cyclic fatigue. In situ repair is extremely difficult. This paper examines the arguments favoring the enclosing of the ent1re reactor in a vacuum buflding and thus changing the character of this closed surface from one requiring absolute vacuum integrity to one of high pumping impedance. Two differentlally pumped vacuum zones are Imagined - one clean zone for the plasma and one for the balance of the volume. Both would be at substantially the same pressure. Other advantages for the vacuum enclosure are also cited and discussed. 
In reviewing the various design studies on fuston reactors from ORNL, Culham, Julich, Frascat1, Princeton, Wisconsin, Brookhaven, and Japan, 1-8 plus the more recent studies on the Experimental Power Reactor (EPR) of ORNL, General Atomic, and Argonne, $9-11$ one is impressed with the depth, scope, and progress of the work that has been accomplished since conceptual design studies were first initlated in 1969. As a word of caution to new readers of fusion system study papers and as a reminder to those who have been in the fleld for some time, we must clearly recognize that these studies are transitory since they must be based on physics and engineering understanding that is neither absolute nor complete, but which is actually in a continuous state of flux. The studies, therefore, must be subject to constant revision as our understanding increases, and no one study or seeming conclusion should be regarded as gospel or as the last word.

The design studies cited above, although they may be inexact and exploratory, are in reasonable depth, and all examine a large number of speciflc problems within the framework of a total reactor so that for the most part the individual problems are not solved by the expedient of obscurely transferring the difficulties elsewhere. This necessary integration of a large number of parts into a credible whole does not lead to simple systems, however. Thus, much as we may be impressed by the scope of the studies, we are likely at the same time to be distressed by the fact that all studies converge with a picture of a fusion reactor that is extremely complicated. I belleve it is fair to say that if a composite were drawn of "everyman's" fusion reactor as presently 
envisioned, and if it included all the elements deemed necessary, it would be so complicated, so susceptible to loss of function, so irreparable, that no agency would fund it and no utility would dare use it. Figures 1-3 show views of the three Experimental Power Reactors (EPRs) - machines that would be precursors to a commercial reactor. They are indeed complicated - even more so than one would be led to believe by an Inspection of these somewhat simplifled figures. They are put together with a juxtaposition of blanket, toroldal colls, pololdal coils, welds, seals, etc., so as almost to defy any kind of reasonable disassembly and maintenance, and yet these EPRs do not include (or give only token attention to) likely necessary additions such as divertors, fuel injectors, neutral beam injectors, vacuum pumps, cryogenic pumps, diagnostic equipment, control equipment, and just plain, garden varlety hardware.

John Clarke has recently taken an objective view of the dilemma of the complicated reactor and suggests that there may be some physics relief in sight. 12 He states that a share of the difficulties arises from the plasma physics scaling laws used heretofore and from some presumed limits on $\beta$, and he suggests that the empirical scaling laws can now be favorably modified based on recent experimental results from the MIT Alcator, from ORNL ORMAK, and from a reassessment of $\beta$ limits in possible future tokamak devices such as TNS (The Next Step) which are heated by neutral beam injection. The scailng law modifleatiuns allow machines with a higher aspect ratio, a higher power density, better B fleld utilization, and (neglecting impurity effects) a longer burn time. The concept of flux conservation provides for high values of $B .13$ The fundamental problems that Clarke feels were encountered in the EPR designs are reproduced here from his paper. 
GAINS FROM

New Physics

1. Inherent unmanageable shape (low aspect rat1o);

2. Pulsed operation;

3. Exacting tolerances on very large components;

4. Radiation damage requiring replacement of internals by totally remote means;

5. Inherent, very low power density;

6. Very large electric power demands;

7. Excessively complex auxiliaries;

8. Questionable breeding potential.
High

Mod

Low

Low

High

Mod

Low

Low

Better Engineering

Low

Mod

High

High

Low

Low

Mod

Mod

I have modified this list by adding two columns to it. One column indicates where the new physics scaling, in my opinton, helps significantly (High), helps moderately (Mod), or does not obviously help (Low). The second column shows the areas, again in my opinton, where better eng1neering ideas and designs would be not only valuable but also probably obligatory. It can be seen that the two disciplines, engineering and physics, must complement one another. If they are able to do so, then with highly plausible updating of plasma physics and substantial inventiveness in engineering, there can emerge a reactor that stands a chance of being a credible machtine. To span the credibility gap, as my friend Peter Mohr of LLL might say, we, as engineers, must add "simplification and lightness" to the fusion machine. If we get too locked in by current Ideas or by current concepts, as I mentioned In the first paragraph, then 
this addition can be Insuperably difficult; if we are receptive to Innovative 1deas, then progress can be made. There is at least one particular route to follow that may lead to simplification and Iightness, the first step of which allows the others to proceed. The first step is to enclose the reactor, the total nuclear island, in a vacuum building. The vacuum building concept has been an important part of the Frascat1 FINTOR conceptual design, ${ }^{4}$ but 1 in that reference was not singled out and discussed as havilng any great technological importance. Since I was actively Involved in the FINTOR design, I would like to make up for that omission and discuss here the advantages of a vacuum enclosure.

The vacuum vessel could be in the form of a spherical or elliptical shell capable of belng maintained at a pressure $<10^{-6}$ torr and divided into two principal vacuum zones - that of the building proper and that of the plasma zone. These would be differentially pumped, the separation between the two being only one of high pumping impedance created, for instance, by a reactor zone covered with thin aluminum foll. In the Italian version, the main containment vessel was an ellipsoid with a major and minor diameter of 60 and $26 \mathrm{~m}$. It was made of concrete to provide biological shielding and lined with steel for vacuum integrity and to serve as a tritium barrier. Vessels of this size and larger have been made by NASA at Plumbrook. ${ }^{14}$ Incidentally, the biological shielding required for a fusion reactor must consist of three to five feet of concrete enclosure - which is thick enough to support the atmospheric structural load. It remains necessary then only to assure that the enclosure has vacuum integrity.

Some of the advantages gained In the use of a. vacuum containment vessel are the following: 


\section{More effective control of heat transfer}

The proximity of $4 \mathrm{~K}$ toroldal field colls and divertor coils to $1000 \mathrm{~K}$ blankets, $500 \mathrm{~K}$ shlelds, room temperature vertical field colls, etc., creates a heat transfer problem that absolutely must be minimized. The penalty pald because of energy transfer Into a cryogenic coll and the consequent refrigerator load is $\sim 500 \mathrm{~W} / \mathrm{W}$. The most effective means for decoupling the energy exchange is to reduce it to a problem of radiation heat transfer and to introduce the use of inexpensive thin foll radiation shields. At a penalty of $500 \mathrm{w} / \mathrm{w}, 100 \%$ of the plasma power generated is non-productively used for refrigeration when the thermal energy loss from the blanket or other thermal surfaces to the coll is equal to only $0.2 \%$. We can perhaps afford a heat leak of $0.002 \%$ of the total blanket energy, or about $20 \mathrm{~kW}$ thermal loss to the cryogentc coils in a $1000-\mathrm{MW}(\mathrm{t})$ reactor. Since this energy can come from any heat source - not just the blanket - thermal isolation is extremely important.

\section{Elimination of all remote field welding in reactor region} The primary vacuum in many of the present reactor concepts is established by peripheral seam welds generally made between adjacent blanket modules. The total length of these welds that must have $100 \%$ integrity against leakage can be thousands of meters. In the event of a leak, it must first be found - no small task - and then repaired. In the event of replacement of blankets, the entire weld must be cut. All the operations leak hunting, repair, cutting, replacement - must almost certainly 
be done remotely, and this is an incredibly difficult task. Furthermore, these weld zones will be subject to both thermal stress and thermal cycling with almost certain leakage with time. These welds are not necessary and can be eliminated by moving the primary vacuum to the room temperature enclosure.

3. Environmental protection for refractories

The refractory metals which are candidates for blanket zone materials - niobium, vanadium, molybdenum, tungsten, titanium, tantalum - cannot be run at elevated temperatures without a protective atmosphere. Cover gases such as argon may be acceptable, but considering the need to minimize insofar as possible all convective and conduction heat transfer, a vacuum background is a better solution.

4. Relaxation of pressure loads

The welding of the blanket modules, one to the next, creates a structure that is effectively an externally loaded pressure vessel. This high temperature vessel is subject to creep buckling. The problem may manifest itself in two ways: if the walls are made thin for good neutronics, good tritium breeding, and minimum neutron heating, they may fail by buckling; if the walls are thick enough to resist buckling at some temperature, $T$, then the additional neutron heating of the thicker material causes the temperature to rise to $T+\Delta T$, again lowering the creep buckling resistance. A sertes of nested blanket modules physically assembled side by side circumvents this potential problem. 


\section{Replacement ease: blanket module}

With the blanket modules assembled as a nested set with a minimum of mechanical connections and no welded connections, it is possible to visualize module replacement with a minimum of difficulty by remote means. The optimum replacement technique could then be one using simple linear translation of first wall or blanket unfts exiting between the coils.

6. Tritlum control: accidental release

The use of a vacuum vessel operating at room temperature creates a highly effective diffusion barrier against tritium release.

\section{Remote handling}

In addition to the blanket modules, there is remote handling involved in a significant number of other reactor components such as injectors - that probably can be repaired or replaced in a total vacuum environment more readily than in one where the vacuum is in only the plasma zone. In fact, anything that penetrates the reactor vessel to communicate in one way or another with the plasma - pressure transducers, temperature transducers, plasma diagnostic probes, etc. - can be much more readily replaced when it does not have to pass through a vacuumtight Intervening wall.

\section{Operation time}

The effective on-line time of the reactor should improve with the use of a vacuum enclosure since the need to let the plasma zone up to air or up to argon is eliminated. This decreases markedly the "bake In" or outgassing times. 


\section{Hands on and remote handling compatibility}

The reasonable concern of experimentalists that a vacuum enclosure is inhibiting and causes an unreasonable difficulty for some experiments is satisfactorily answered by the fact that pumpdown time from atmospheric pressure to $10^{-6}$ torr is approximately 10 hours for facilities such as Plumbrook having a larger volume than would be required for a fueion reactor. Thus, work or experiments requiring "hands on" operation (neglecting the problems of radiation) could be done within a 24-hour period. For the remainder of the experiments, tests, routine maintenance, etc., the vacuum could be retained. Bear in mind, however, that a fusion reactor, prototype or commercial, is no longer a physics experiment and hands on access is not inherent in the design.

10. Reduction of physical size

The elimination of welds which would have established the primary vacuum in the region of the plasma or the blanket if a vacuum building were not used also eliminates the need to provide space and access to these welds. This can reduce the total reactor diameter as much as $2-3 \mathrm{~m}$.

There are lesser advantages and some disadvantages for the introduction of a vacuum building as part of a fusion complex. The disadvantages and the means to clrcumvent them are cited below.

1. Large surface areas and continuous outgassing

The differential pumping of the plasma zone and the remaining volume minimizes this problem. Simple, high impedance closures can be made such as spring clips, baffles, 0-rings, or metal bonds that are easily placed or removed. 
2. Components that "abhor". vacuum

There are undoubtedly some components that function more effectively in a normal pressure environment - parts with low vapor pressure characteristics such as lubricated bearings, certain parts of injectors that may arc or have corona discharge, etc. These parts are outside of the blanket shield zone and can be individually. pressurized.

3. Vacuum welding

Within the blanket shield area there is the problem that adjacent parts operating at high temperature may vacuum-fuse together if they are initially in physical contact. The simple closures mentioned in (1) must therefore include a coating or barrier that prevents the weld. Further study is needed here.

4. The vacuum building itself

The building of a large vacuum enclosure is not trivial. However, the biological shielding required anyway $(\sim 2 \mathrm{~m}$ of concrete) can certainly also be used as structure. The NASA space program experience would be helpful here.

There may be a fear or reservation that vacuum enclosures of the physical size needed to house a fusion reactor are structurally unreasonable or visionary or too costly. This incorrect assumption is countered by the existence of the NASA Plumbrook facility. A cross section of that facility is reproduced in Fig. 4. I have registered on the figure the approximate dimensions of the ORNL fusion power DEMONSTRATION POWER REACTOR or TNS, both of which are currently under study. Clearly the volume, the dimensions, and the shielding would be more than adequate. Figure 5 shows a plan view of the facility including assembly areas, disassembly areas, hot cells, 
offices, cryogenic areas, etc. - in short, everything needed in a representative way for a fusion reactor factlity. Plumbrook, in 1962 dollars, cost $\sim \$ 29 \mathrm{M}$ as indicated in the cost breakdown of Table 1 . In terms of 1976 dollars, using an average escalation rate of $6.5 \%$ for labor and materials, the cost would be $\sim \$ 70 \mathrm{M}$. I have indicated with a check mark $(\checkmark)$ those items on the cost breakdown uniquely related to the vacuum system. They amount to about $33 \%$ of the total. These added costs may be more than recovered by savings in the reactor const.

The idea, it seems to me, is worthy of sertous consideration and further study - perhaps for TNS. 
Table 1. Space power facllity: actual construction costs representative of 1962-1963 dollar values

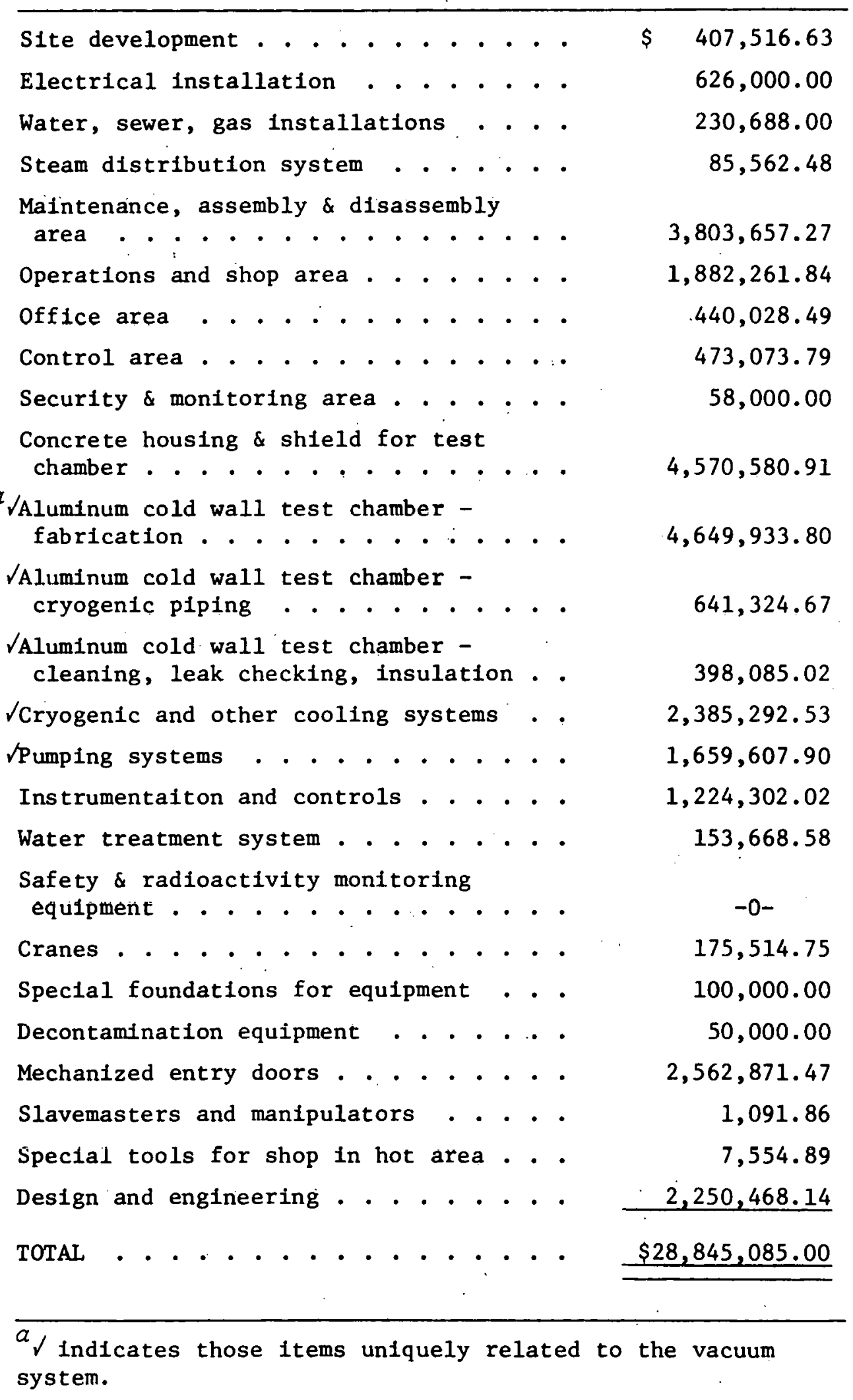




\section{REFERENCES}

1. A. P. Fraas, Conceptual Design of the Blanket and Shield Region and Related Systems for a FulZ-Scale Toroidal Fusion Reactor, ORNL/TM-3096, Oak Ridge (May 1973).

2. J. T. D. Mitchell and J. A. Booth, Wall Loading Limitations in a Helium Cooled Fusion Reactor Blanket, CLM-R126, UKAEA Research Group, Culham Laboratory, Paper No. 13 of Workshop of Fusion Reactor Des1gn Problems, January 29, 1974 chrough February 13, 1974.

3. S. Forster, "Closed Helium-Turbine Cycle with a Fusion Reactor," Mechanical Engineering, 13 (August 1973).

4. E. Bertolini et a1., Design of a Minimum Size Toroidal D-T Experimental Reactor, IAEA-CN-33-G1-1, Laboratorl Nazionall del CNEN, Frascati, Italy (1973).

5. R. G. Mills (ed.), A Fusion Power Plant, MATT-1050, Princeton Plasma Physics Laboratory, Princeton, New Jersey (August 1974).

6. The University of Wisconsin Fusion Feasibility Study Group, $A$ Wisconsin I'oroidal Fusion Reactor Design, Vol. 1, UWFDM-68 (November 20, 1973).

7. J. R. Powe11, F. T. Miles, A. Aronson, W. E. Winsche, Studies of Fusion Reactor Blankets with Minimum Radioactive Inventory and with Tritium Breeding in Solid Lithizm Compounds: A Preliminary Report, BNL 18236, Brookhaven National Laboratory, Upton, New York (Junie 1973).

8. K. Sako, H. Yamato, M. Ohta, Y. Seki, K. Tanaka, N. Asami, S. Matsuda, Y. Ohkubo, T. Takeda, and S. Mori, Design Study of a Tokamak Reactor, IAEA-CN-33/G1-5, Japan Atomic Energy Research Institute, Toka1, Ibaraki, Japan (1973). 
9. M. Roberts and E. Bettis, Oak Ridge Tokamak Experimental Power Reactor Study Reference Design, ORNL/TM-5042, Oak Ridge (November 1975).

10. T. Ohkawa, Conceptual Design Study for a Fusion Experimental Power Reactor, Research Project 323, General Atomic Co., San Diego, California (June 1975).

11. W. M. Stacey, Jr. (project manager), Tokomak Experimental Power Reactor Studies, ANL/CTR-75-2, Argonne National Laboratory, Argonne, Illinois (June 1975).

12. J. F. Clarke, EPR and TNS, ORNL/TM-5418, Oak Ridge (March 1976).

13. J. F. Clarke, High Beta Flux Conserving Tokamaks, ORNL/TM-5429, Oak Ridge (June 1976).

14. Space Power Facility: Description and Copabilities, NASA, Lewis Research Center, Plumbrook Station, Sandusky, Ohio (June 1974). 


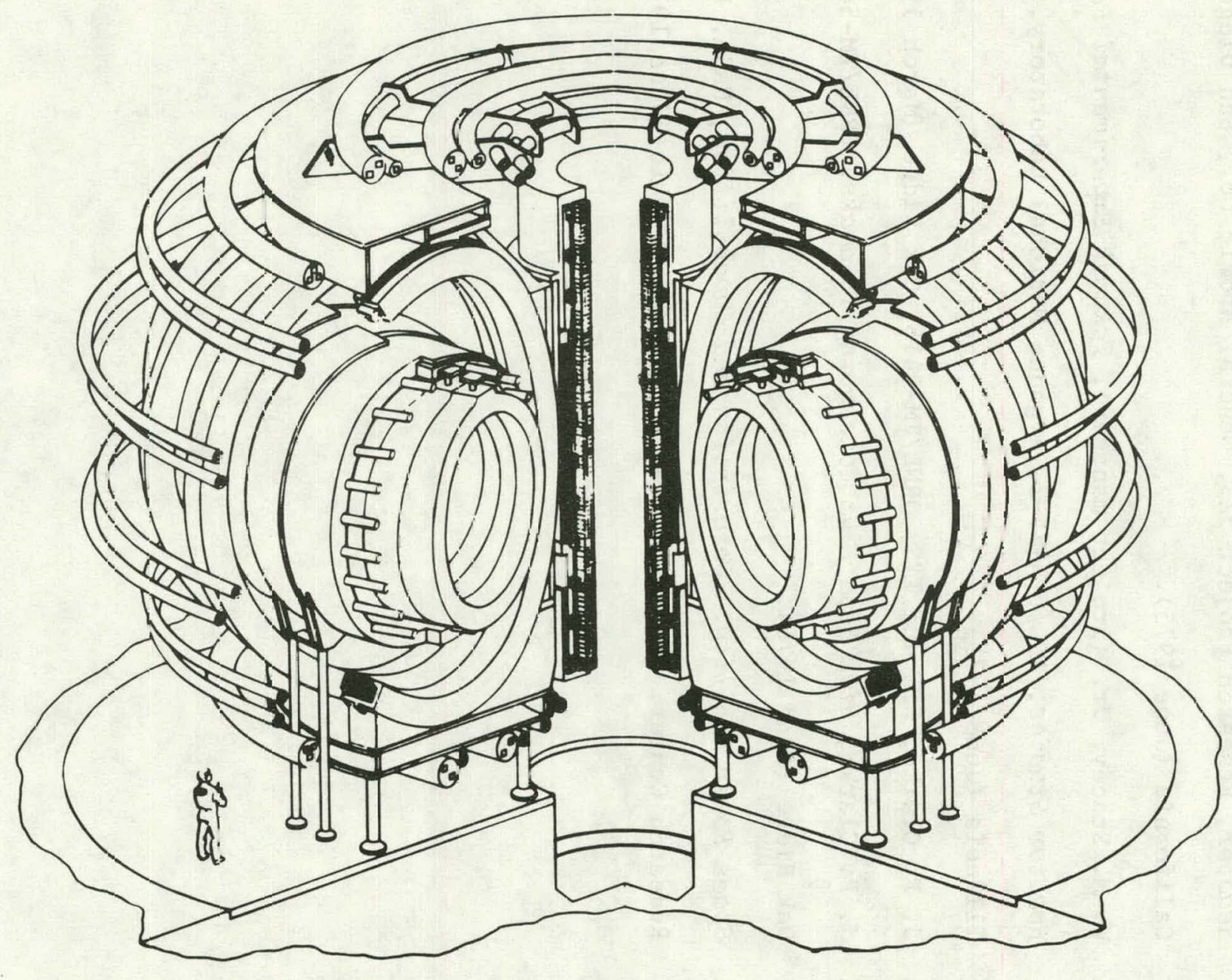

Fig. 1. Oak Ridge EPR reference design. 


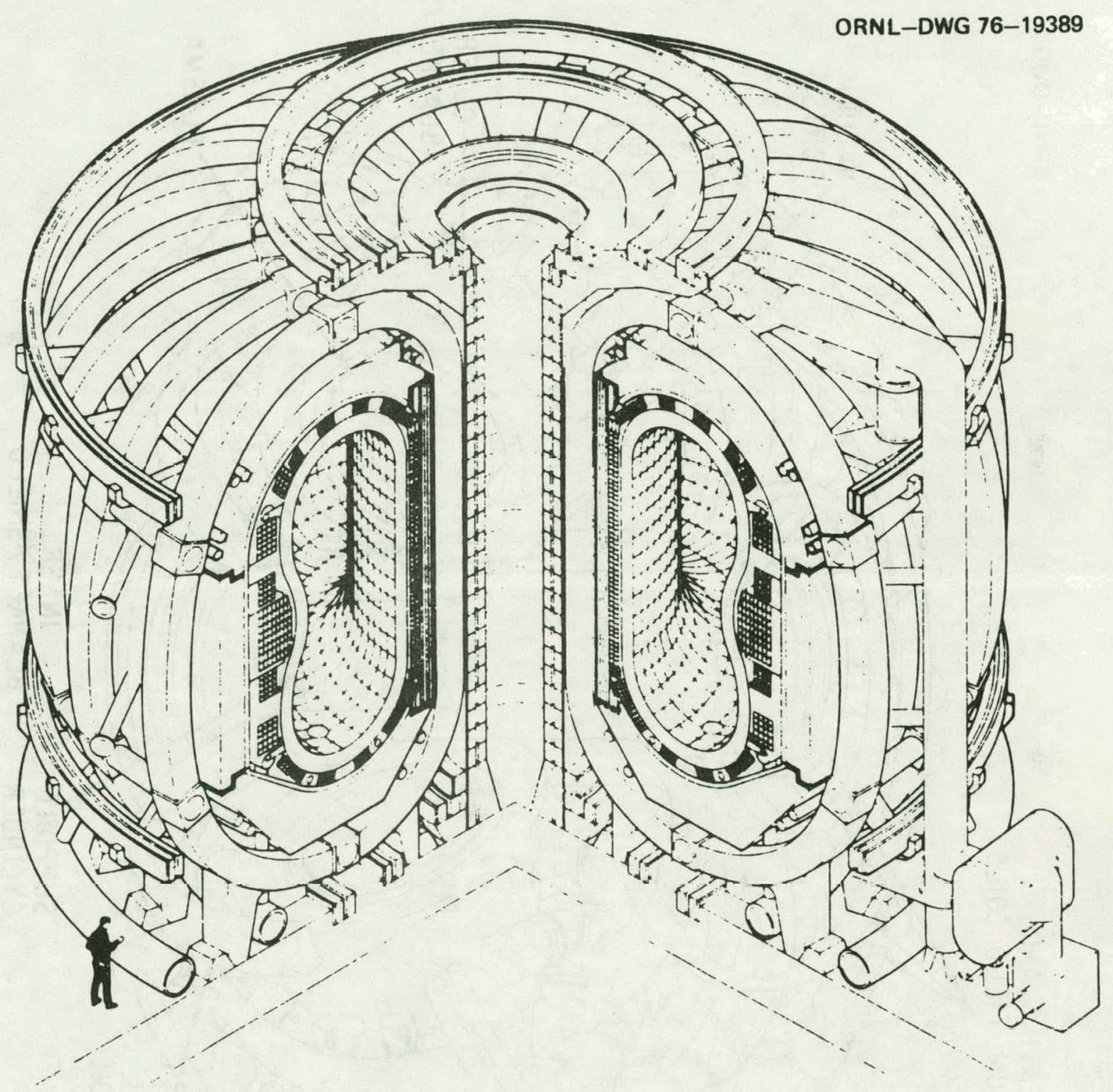

Fig. 2. Argonne National Laboratory, Tokamak Experimental Power Reactor. 


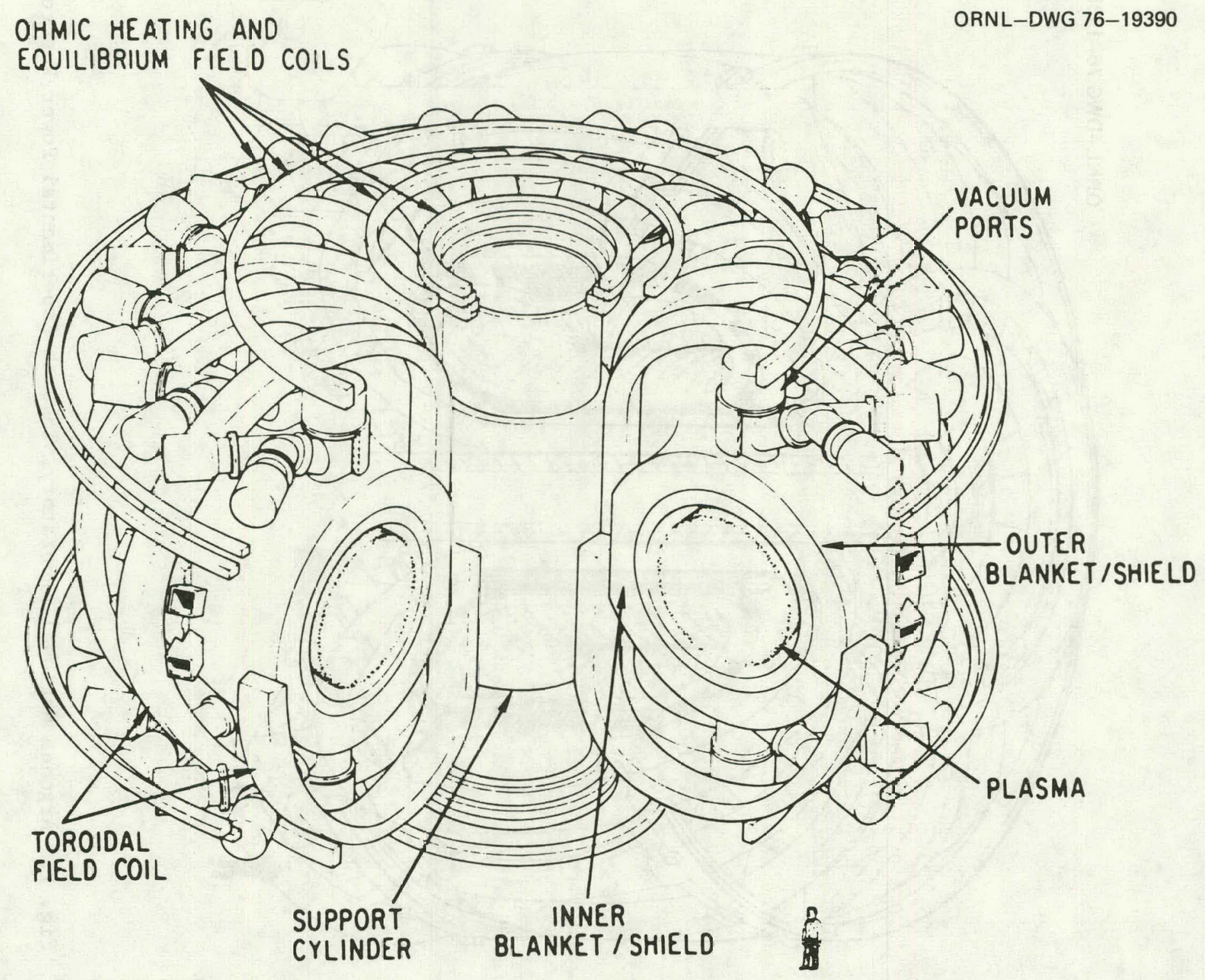

Fig. 3. General Atcmic Experimental Fusion Power Reactor. 


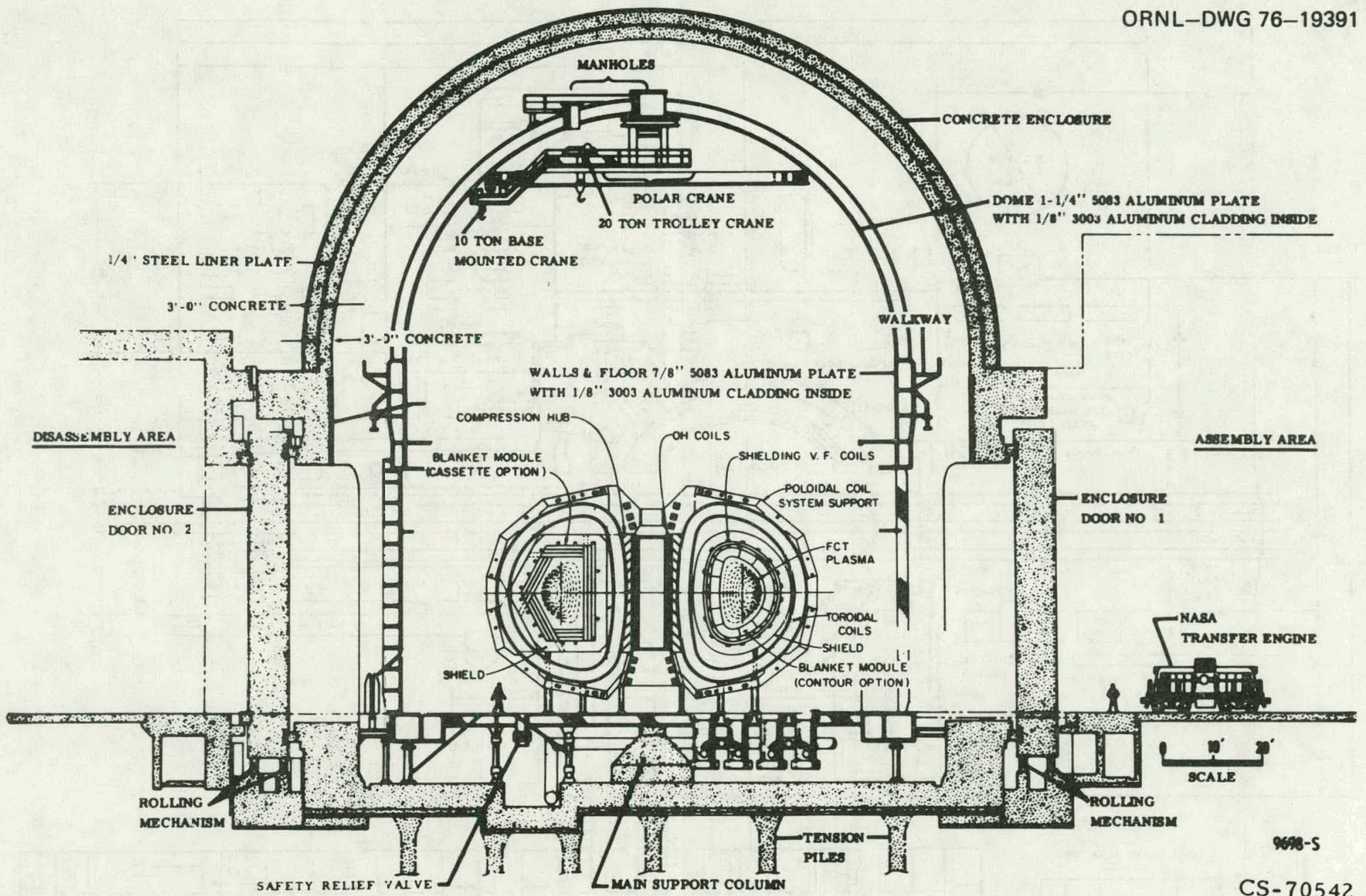

Fig. 4. Cross section through test chamber - Space Power Facility. 


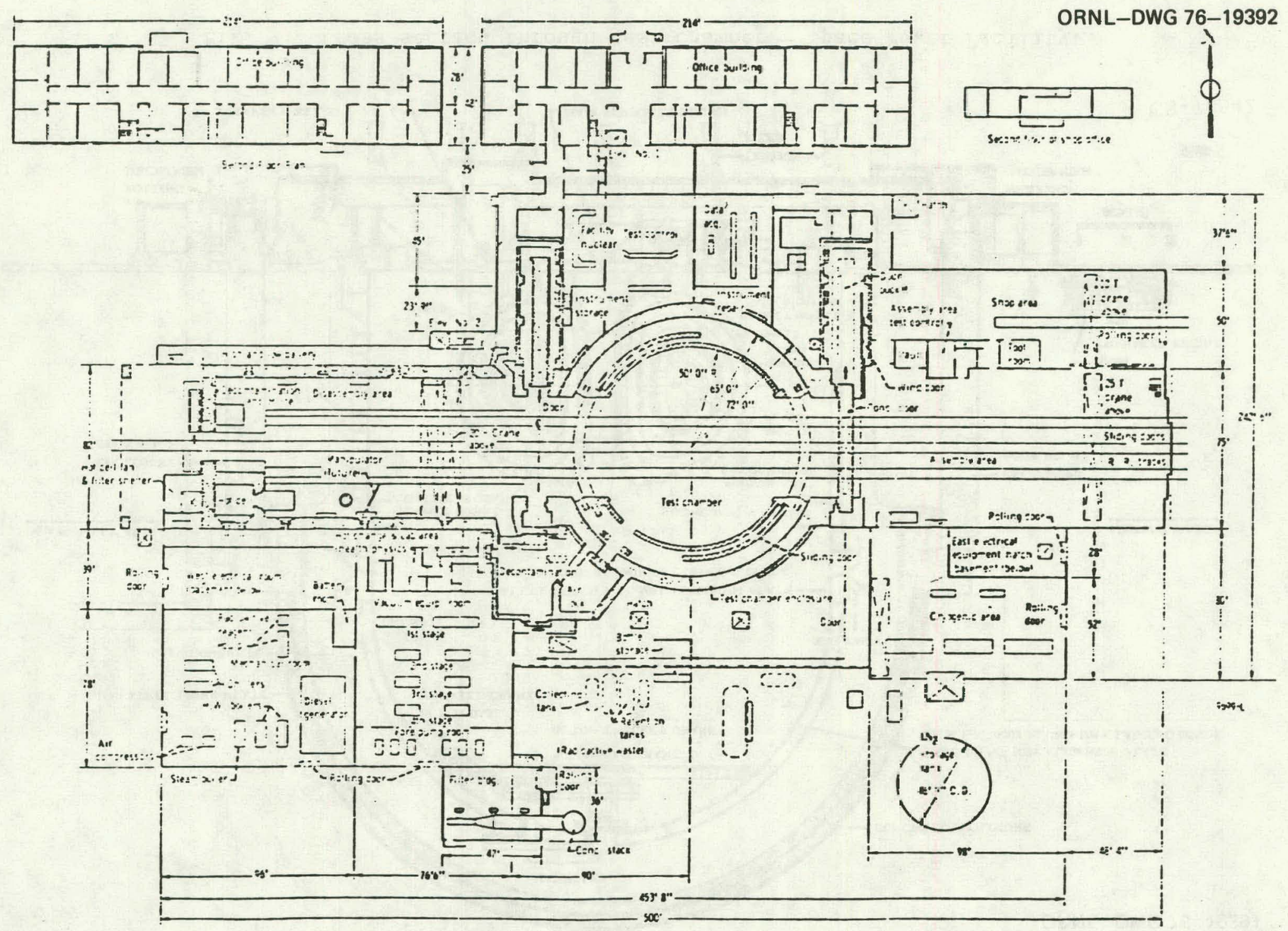

Fig. 5. Space Power Facility plan view. 
ORNL/TM-5664

Dist. Category UC-20

\section{INTERNAL DISTRIBUTION}

$\begin{array}{ll}\text { 1. } & \text { E. S. Bettis } \\ \text { 2. } & \text { J. F. Clarke } \\ \text { 3. } & \text { J. H. DeVan } \\ \text { 4. } & \text { C. F. Fisher } \\ \text { 5. } & \text { A. P. Fraas } \\ \text { 6. } & \text { T. Huxford } \\ \text { 7. } & \text { M. S. Lubel1 } \\ \text { 8. } & \text { H. McCoy } \\ \text { 9. } & \text { A. T. Mense } \\ \text { 10. } & \text { R. Miske11 } \\ \text { 11. } & \text { L. Reld } \\ \text { 12. } & \text { M. Roberts }\end{array}$

\author{
13. J. L. Scott \\ 14. D. Steiner \\ 15. W. C. T. Stoddart \\ 16. H. L. Watts \\ 17. B. Wells \\ 18-41. R. Werner \\ 42. F. W. Wiffin \\ 43-44. Central Research Library \\ 45. Document Reference Section \\ 46. Patent office \\ 47=48. Laboratory Records \\ 49. Laboratory Records RC
}

\section{EXTERNAL DISTRIBUTION}

50. T. Batzer, Lawrence Livermore Laboratory, Livermore, CA 94550.

51. J. W. Beal, Offlce of Development and Technology, Division of Magnet1c Fuston Energy,. Energy Research and Development Administration, Washington, DC 20545.

52. D. Beard, Division of Magnetic Fusion Energy, Energy Research and Development Administration, Washington, DC 20545.

53. R. Behrisch, Max-Planck-Institut fuer Plasmaphysik, D8046 Garching/ Munchen, Germany.

54. A. Belozerov, International Atomic Energy Agency, Kartner Ring 11, P. 0. Box 590, A-1011 Vienna, Austria.

55. E. Bertolini, CNEN, Laboratori Gas Ionizzati, Frascati, Italy.

56. M. Biggio, EURATOM, Ispra, Italy.

57. S. Bobbio, Instituto di Elettrotechnia, Università di Napoli, Italy.

58. B. Brunel11, CNEN, Laboratori Gas Ionfzzat1, Frascat1, Italy.

59. R. W. Bussard, Cerberonics, Inc., 7312 Convoy Court, San Diego, CA 92111 .

60. G. A. Carlson, University of California, Lawrence Radiation Laboratory, P.0. Box 808, Livermore, CA 94550.

61. R. Carruthers, United Kingdom Atomic Energy Agency, Culham Laboratory, Abingdon, Berkshire, England.

62. G. Casini, EURATOM, Ispra, Italy.

63. E. Coccorese, Instituto di Elettrotechnia, Università di Napoli, Napoli, Italy .

64. F. E. Coffman, Division of Magnetic Fusion Energy, Energy Research and Development Administration, Washington, DC 20545.

65. R. Cunebert1, EURATOM, Ispra, Italy.

66. J. Darvas, Institut fuer Plasmaphysik, KFA Julich GMBH, D517 Julich, Postfach 365, West Germany.

67. S. 0. Dean, Assistant Director, Office of Confinement Systems, Energy Research and Development Administration, Washington, DC 20545. 
68. L. Egiziano, Instituto di Elettrotechnia, Università di Napoli, Napoli, Italy.

69. F. Farfallett1-Casali, EURATOM, Ispra, Italy.

70. H. K. Forsen, Jersey Nuclear Company, 777 106th Avenue, NE, Beilevue, WA 98004

71. T. K. Fowler, University of California, Lawrence Radiation Laboratory, P.0. Box 808, Livermore, CA 94551.

72. M. B. Gottlieb, Princeton Plasma Physics Laboratory, Princeton University, Princeton, NJ 08540.

73. W. C. Gough, Electric Power Research Inst., 3412 Hillview Avenue, P.0. Box 10412, Palo Alto, CA 94304.

74. 0. Greco, Instituto di Elettrotechnia, Universita di Napoli, Napoli, Italy.

75. G. K. Hess, Jr., Senior Sclentific Advisor, Division of Magnetic Fusion Energy, Energy Research and Development Administration, Washington, DC 20545.

76. Toru HIraoka, National Laboratory, Japan Atomic Energy Research Institute, Tokai, Ibarak1, Japan.

77. R. L. Hirsch, Director, Divison of Magnetic Fusion Energy, Energy Research and Development Adminstration, Washington, DC 20545.

78. M. R. Hoffman, Lawrence Livermore Laboratory, L-383, Livermore, CA 94550 .

79. George Hopkins, Gulf General Atomic Co., P.0. Box 608, San Diego, CA 92112 .

80. T. Kammash, Nuclear Englneering Department, College of Engineering, University of Michigan, Ann Arbor, MI 48105.

81. Ron Kostoff, Division of Magnetic Fusion Energy, Energy Research and Development Administration, Washington, DC 20545.

82. G. L. Kulcinski, Department of Nuclear Engineering, University of Wisconsin, Madison, WI 53706.

83. Librartan, Department of Physics and Astronomy, Universtty of Iowa, Iowa City, IA 52240.

84. Lawrence Lidsky, Department of Nuclear Engineering, Massachusetts Institute of Technology, Cambridge, MA 02139.

85. G. McCracken, United Kingdom Atomic Energy Agency, Culham Laboratory, Abingdon, Berkshire, England.

86. B. Miller, Division of Magnetic Fuston Energy, Energy Research and Development Administration, Washington, DC 20545.

87. R. G. Mills, Princeton Plasma Physics Laboratory, Princeton University, Box 451, Princeton, NJ 08540.

88. J. Mitche11, Unlted Kingdum Atumle Enelgy Ageily, Culliam LAboratory, Abingdon, Berkahire, England.

89. M. Nozawa, Thermonuclear Fusion Laboratory, Japan Atomic Energy Research Institute, Oarai, Ibarak1, Japan.

90. T. Ohkawa, Gulf General Atomic, P.0. Box 608, San Diego, CA 92212

91. F. Peter, EURATOM, Ispra, Italy .

92. L. Price, Division of Magnetic Fusion Energy, Energy Research and Development Administration, Washington, DC 20545.

93. .F. Ribe, Los Alamos Scientific Laboratory, P.0. Box 1663, Los Alamos, NM 97544. 
94. David Rose, Department of Nuclear Engineering, Massachusetts Institute of Technology, Cambridge, MA 02139.

95. W. M. Stacey, Jr., Argonne National Laboratory, 9700 South Cass Avenue, Argonne, IL 60439.

96. F. Tenney, Princeton Plasma Physics Laboratory, Princeton University, Box 451, Princeton, NJ 08540.

97. K. Thomassen, P.0. Box 1663, Los Alamos Scientific Laboratory, Los Alamos, NM 87544.

98. Romano Tosch1, CNEN, Laborator1 Gas Ionizzat1, Frascat1, Italy.

99. J. M. Williams, Division of Magnetic Fusion Energy, Energy Research and Development Administration, Washington, DC 20545.

100. K. Zwilsky, Division of Magnetic Fusion Energy, Energy Research and Development Administration, Washington, DC 20545.

101. Director, Research and Technical Support Division, ERDA-ORO, P.O. Box E, Oak Ridge, TN 37830 .

102-281. Given distribution as shown in TID-4500, Controlled Thermonuclear Processes (25 copies NTIS). 